\title{
The Question of Construction Cluster Efficiency in Russian Regions
}

\author{
Aleksandr Voronin $^{1, *}$, Aleksandr Kuvshinov ${ }^{1}$, and Miroslava Gusarova ${ }^{2}$ \\ ${ }^{1}$ Tyumen State University, 625003 Semakova str. 10, Tyumen, Russia \\ ${ }^{2}$ Industrial University of Tyumen, 625001 Volodarskogo str. 38, Tyumen, Russia
}

\begin{abstract}
This article is devoted to the questions of building complex clasterization in Russian regions. The correlation analysis between the existence of the formed building cluster in each region and the volume of construction works fulfilled during the period under review is being conducted on the basis of data about the development of Russian regions generalized by Federal state statistics service. The authors examine the volumes of construction works in leading regions from the position of clusterization features, describing and analyzing key efficiency problems of construction. The authors draw a conclusion that declared cluster creation is not always based on factual building complex clusterization. As result, current situation in Russian economy seems to be problematic: regions without legally formed clusters are, in fact, more clusterized then those with announced formation.
\end{abstract}

\section{Introduction}

Regional building complex is a certain basis for social-economic changes at all levels of economic development. It should be noted, that the significance of building complex is great for both social-economic development and formation of positive environment for favorable living conditions. This makes it necessary to study regional building complex structure and economic aspects of investment and construction activities regulation [15].

Undoubtedly, the volume of construction works affects Gross Regional Product (Graph 1 - the summary volume of construction works in Russia), it is confirmed by the analysis of statistic data [12] about Russian regions development during the period of 2010-2013.

\footnotetext{
* Corresponding author: vrnnaea@mail.ru
} 


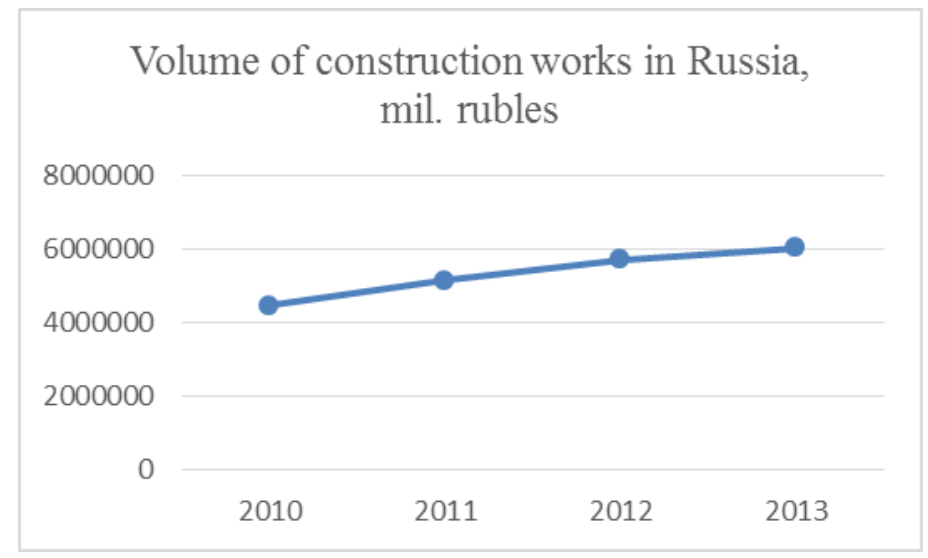

Fig. 1. The summary volume of construction works in Russia

It should be taken into consideration that the GRP dynamics`graph extensively follows the graph of construction works volume dynamics' and on this basis it is possible to make a conclusion about their correlation (Fig. 2).

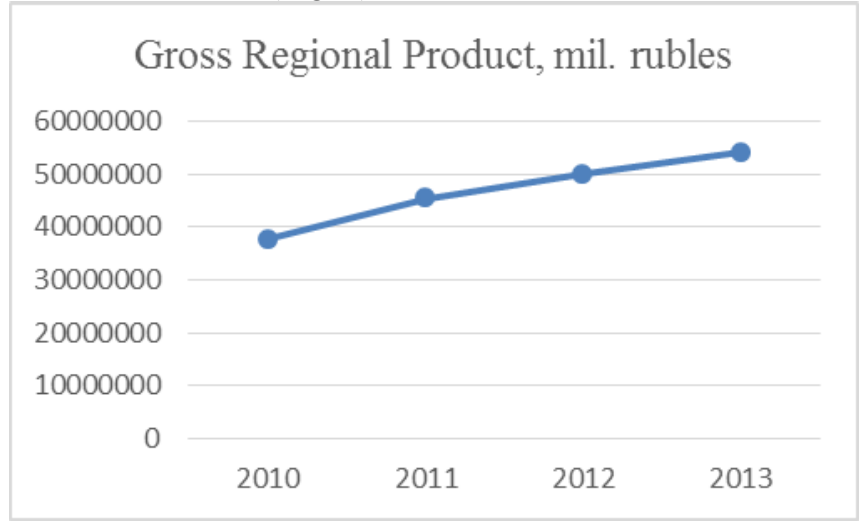

Fig. 2. Gross regional product

The graph of Gross Regional Product looks similarly and presents more precise statistic index (Fig. 3).

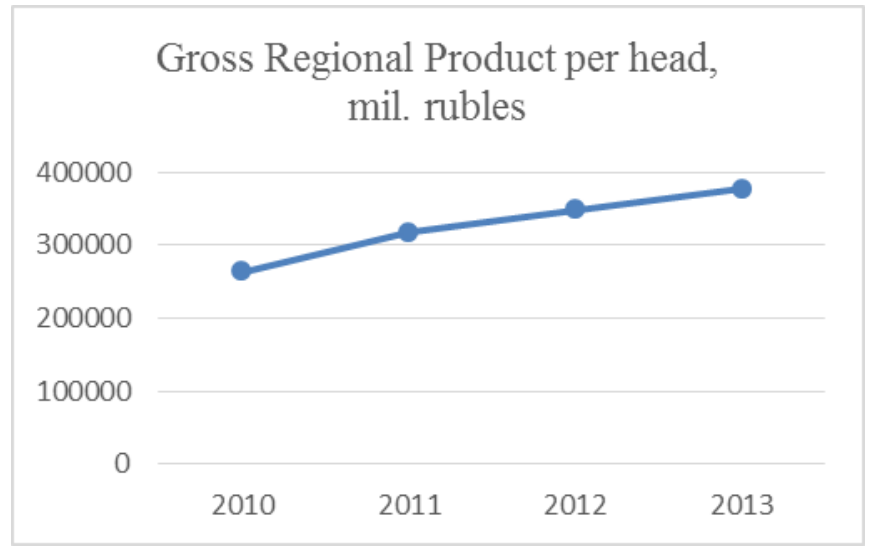

Fig. 3. Gross regional product per head 
In that way, increase of building complex efficiency in Russian regions is especially important for basic assets extension, related industries development and general stimulation of economic growth.

As Garkina I.A. and Garkin I.N. noted [17], nowadays, most of regional departments and ministries in the construction industry have become no more than construction project requesters, which are, in turn, financed from the budget. Self-regulated unions of builders, designers and engineers work independently while construction industry, infrastructure, construction science and professional education have been left out of integration process. The lack of precise interaction between organizations of construction brunch becomes an obvious problem. So, it's necessary to create construction clusters to form the foolproof collaboration mechanism. It should be mentioned, that cluster implies a concentrated group of interconnected organizations (commercial, educational, social etc.), which supplement each other and intensify competitive advantage of separate companies and cluster in general [12].

\section{Theory or experimental methods}

The object of study are the building complexes in Russian regions, analyzed from the position of cluster approach.

«In this case, interpretation of construction cluster regarding the content is close to the concept of "investment-building complex". Most theoretical and practical publications authors widely presented in economic literature, agreed, that investment-building complex is a number of organizations, not only practicing construction, reconstruction and enlargement of functioning industrial and non-industrial building and constructions, but also providing the fulfilling of these works with material and technical resources and transport services, carry out theoretical and practical works, designing development activities and preparing the staff» [19].

It should be noted, that economic cluster in Russian economy is being interpreted from positions of wide approach, because the category "cluster" is often used as a synonym for categories "sector", "complex" and "brunch" [5].

As Matveeva O.A. noted [8], the social effect of clusterization in construction cluster appears to be an increasing level of habitation availability. The statistic data shows that joining of companies within a cluster resolves this problem.

In regions, where construction cluster is being formed, residential housing volumes are considerably bigger. The presence of providing element (banks etc.) in cluster, legal state regulation and cluster system stability allow to increase this index by providing citizens with available hypothecary credits with guarantied job entry terms.

\section{Results}

The analysis shows that the following regions are the leaders in construction works volume in 2013: leading by ahead, Moscow with 674276.8 mil. rubles, Tyumenskaya oblast (506941,6 mil. rubles, where 229549.6 mil. rubles are provided by Khanty- Mansi Autonomous Okrug - Yugra), Krasnodarskiy kray (480663.6 mil. rubles), SaintPetersburg (375803.6 mil. rubles), Tatarstan Republic(297459,9 mil. rubles), Moskovskaya oblast (289351,4 mil. rubles). It should be noted, that every region from this list works on the basis of the cluster conception in construction or already has a developed construction cluster.

The Moscow innovation industrial-building cluster has been functioning since 2015 in Eastern administrative district, but specific weight of industrial brunch organizations was 
accumulated during a long period of time and we can now talk about the functioning of the cluster in potential form, consolidating 16 companies [9].

The statistics of 2013 shows that the reconstruction of 56 investment objects (with value over 100 mil. rubles) had been finished in Krasnodarskiy kray [11]. It`s extensively caused by a global preparation for Sochi Olympic Games 2014, within which the cluster approach in construction was widely used and consolidated investors, builders, contracting organizations, responsible for infrastructure objects' development, state authorities and banks etc. [16].

It is also possible to establish the natural (Tyumenskaya oblast, Moskovskaya oblast) or purposeful (Saint-Petersburg, Tatarstan) clusterization in other regions as well.

But the experience of regions, which aren 't leaders in construction works volume, but already have a formed construction cluster, is more interesting for regional economy in context of building complex clusterization efficiency evaluation. Nowadays, there are active construction clusters in Voronezhskaya oblast, Kaluzhskaya oblast, Novosibirskaya oblast, Sverdlovskaya oblast, Nizhegorodskaya oblast, Samarskaya oblast, Belgorodskaya oblast, Vologodskaya oblast and Permskiy kray.

These regions are included into the Top-25 of 83 Russian regions (2013, before constitution of Crimea Republic and federal city Sevastopol) regarding the volume of construction works except Vologodskaya oblast (35 place) and Kaluzhskaya oblast (39 place) in 2013. However, the comparison of Russian regions using other criteria is necessary for more detailed analysis.

The key factor, providing the construction works volume, is investment. The analysis of investment in building complex in 2013 clarifies the leadership of Moscow (575129.3 mil. rubles), Saint-Petersburg (261807.1mil. rubles), Moskovskaya oblast(347298.2 mil. rubles) and Tyumenskaya oblast(828802.3mil. rubles), Tatarstan (332261.4 mil. rubles) and Krasnodarskiy kray (727868.5 mil. rubles) are under the average level of investment (within Russia - 9560.3 mil. Rubles).

The investment in construction complex is comparatively lower in the regions with formed clusters: Sverdlovskaya oblast - 164811.8 mil. rubles, Nizhegorodskaya oblast 144374,4 mil. rubles, Samarskaya oblast 139454 mil. rubles, Voronezhskayaoblast 126935.1 mil. rubles, Permskiy krai - 103601.2 mil. rubles, Novosibirskaya oblast 97150.9 mil. rubles, Belgorodskaya oblast -82560.4 mil. rubles, Saratovskaya oblast 60248.6 mil. rubles, Kaluzhskaya oblast -59340.8 mil. rubles, Vologodskaya oblast 50456.6 mil. rubles.

It should be mentioned that organizational factors, such as work organization level in construction, builders' qualification, business process mechanization, level of technical equipment, new building technologies integration, supply chain service etc. are very important. Provided that the other things are equal, these factors will guarantee the competitive advantage. The clusterization of building complex in Russian regions is aimed at development of these factors.

So, the regions with active construction clusters show more progressive results under comparable investment (see table 1). The remaining behind - Vologodskaya oblast 50456.6 mil. rubles of investment and construction works volume of 48862.7 mil. rubles) demonstrates a big separation from the following Tverskaya oblast (investment in construction - 50254.4 mil. rubles) with 16457.2 mil. rubles. In that way, it's generally possible to speak about greater investment efficiency in regions with institutionalized construction clusters. 
Table 1. Compare of construction works volume depending on investment in Russian regions with and without clusters [million rubles]

\begin{tabular}{|c|c|c|c|c|c|}
\hline $\begin{array}{l}\text { Region (with } \\
\text { cluster) }\end{array}$ & $\begin{array}{l}\text { Construction } \\
\text { works } \\
\text { volume in } \\
2013\end{array}$ & $\begin{array}{c}\text { Investment } \\
\text { building } \\
\text { complex in } \\
2013\end{array}$ & $\begin{array}{l}\text { Comparable } \\
\text { region without } \\
\text { cluster }\end{array}$ & $\begin{array}{c}\text { Construction } \\
\text { works } \\
\text { volume in } \\
2013\end{array}$ & $\begin{array}{c}\text { Investment } \\
\text { building } \\
\text { complex } \\
\text { in } 2013\end{array}$ \\
\hline $\begin{array}{l}\text { Sverdlovskaya } \\
\text { oblast }\end{array}$ & 107171.5 & 164811.8 & $\begin{array}{l}\text { Tyumenskaya } \\
\text { oblast (without } \\
\text { Autonomous } \\
\text { Okrugs) } \\
\end{array}$ & 135564.4 & 160502.2 \\
\hline $\begin{array}{l}\text { Nizhegorodskaya } \\
\text { oblast }\end{array}$ & $142638 / 3$ & 144374.4 & \multirow{2}{*}{$\begin{array}{l}\text { Rostovskaya } \\
\text { oblsast }\end{array}$} & \multirow{2}{*}{126462.5} & \multirow{2}{*}{141268} \\
\hline $\begin{array}{l}\text { Samarskaya } \\
\text { oblast }\end{array}$ & 139333 & 139454 & & & \\
\hline $\begin{array}{l}\text { Voronezhskaya } \\
\text { oblast }\end{array}$ & 68720 & 126935.1 & $\begin{array}{l}\text { Sakha (Yakutia) } \\
\text { Republic }\end{array}$ & 65690.5 & 128974.8 \\
\hline Permskiykray & 85927.1 & 103601.2 & Irkutskaya oblast & 94617 & 106233.5 \\
\hline $\begin{array}{l}\text { Novosibirskay } \\
\text { aoblast }\end{array}$ & 69909.2 & 97150.9 & $\begin{array}{l}\text { Chelyabinskay } \\
\text { aoblast }\end{array}$ & 78704.3 & 94799.1 \\
\hline $\begin{array}{l}\text { Saratosvskaya } \\
\text { oblast }\end{array}$ & 59730.6 & 60248.6 & $\begin{array}{l}\text { Volgogradskaya } \\
\text { oblast }\end{array}$ & 58597.4 & 76670.6 \\
\hline $\begin{array}{l}\text { Belgorodskay } \\
\text { aoblast }\end{array}$ & 71282.4 & 82560.4 & Primorskiy kray & 62685.6 & 82450.9 \\
\hline $\begin{array}{l}\text { Kaluzhskaya } \\
\text { oblast }\end{array}$ & 42436.3 & 59340.8 & Lipetskaya oblast & 34266.8 & 64396.2 \\
\hline $\begin{array}{l}\text { Vologodskaya } \\
\text { oblast }\end{array}$ & 48862.7 & 50456.6 & Tverskaya oblast & 16457.2 & 50254.5 \\
\hline
\end{tabular}

The analysis of introduced data clearly shows that some regions with an active construction cluster are more effective in implementation of investment in building complex. Comparison of these regions is interesting and purposed to discover cluster advantages and disadvantages in concerned regions of Russian Federation.

As U.G. Lavrikova and S.N. Kotlyarova [7] noted, that every cluster was created with different aims according to the region needs. The Ural construction cluster in Sverdlovskaya oblast declares an increase of regional building complex efficiency and competitiveness, saving of market positions and widening of market to be the general goal. The aim of Saratov interregional research-and-production cluster is formation of machinebuilding complex for innovation materials integration in construction in order to decrease the price of a habitation square metre, in other words, the increase of construction works volume wasn't even presumed as a main goal. The Volgograd international cluster focuses on foreign progressive technologies attraction in order to develop the new brunch - timber house-building. The success of such an achievement directly influence construction works volume as well, so it is clear to see within the introduced statistic data.

Let's separately examine problems of least successful regions in 2013 with active construction clusters.

The Ural construction cluster began its activity in 2013. As U.N. Chumerin [18], the director of noncommercial partnership "Ural construction cluster" noted, that the actual problem of Sverdlovskaya oblast is the fact, that the biggest building and infrastructural projects, such as 2018 FIFA World Cup, inevitably attract engineering companies from Moscow and Saint-Petersburg, which constantly win the tenders,so it's very difficult for companies from Sverdlovskaya oblast to compete with them. Exactly this problem caused 
the necessity of cluster creation in order to consolidate the efforts of the local building organizations to fight for local projects.

Nowadays, the activity of the cluster pays off [10].The cluster consolidates 167 organizations, 15 mil. rubles are put into operations. In that way, this cluster provides more than $10 \%$ of the whole construction works volume of Sverdlovskaya oblast.

The problem of Novosibirsk construction cluster (common for many Russian clusters) is the fact, that it was institutionalized, but actually this structure doesn 't correspond to cluster concept by Michael Porter. The reason is insufficient degree of clusters understanding in Russia, connected to aspiration for their presence declaration as soon as possible. As A. Nizkovskikh [4], the director of State government institution of Novosibirskaya oblast "The center of regional development" noted, this center's aim for the next few years is an annual formation of 2-3 clusters. As a result, the cluster creation happens for the government's sake, but the degree of cluster maturity (accumulation of companies, their interdependence, active collaboration with scientific institutions etc.) isn 't taken into account.

There is the same problem in Permskiy kray. The building complex is concentrated in some degree, but it would be incorrect to speak about the presence of the formed cluster. V. Fedorovskiy, the minister of building, housing and communal services of Permskiy kray ,describes a cluster as 4873 building companies and institutions [2]. Accordingly, the regional government makes an attempt to clusterize the huge building complex at the same time instead of gradual attraction of companies to a big thematic organisation (or several of them). As a result, it's rather difficult to organize a system of effective intercommunications between companies fast. However, the positive dynamics of cluster development is seen already today, especially in habitation building. Permskiy kray enters more then 1 Mil. Square metres of habitation for the second year running. The annual temps of habitation building growth make up to $10 \%$. It should be mentioned, that the region couldn't achieve the index of 1 Mil. Square metres for more then years. Lately, Permskiy kray entered over 1 Mil. Square metres - 1269000 - in 1990 (former Permskaya oblast).

Fast growth of construction works has been showed since $2012-9,9 \%$, from 76933,6 up to 84523,6 Mil. rubles in actual prices.

The cluster "Industry of building materials" in Voronezhskaya oblast is also insufficiently worked over, that was confirmed by its failure within the contest of Ministry of economic development getting some state support, where the independent expert commission sifted it out at the first stage, because one of the most important criteria was collegiate style. This cluster was examined as a project of "Domostroitelniy combinat" corporation with the calling of other companies.

It should be mentioned, that requests of at least several legal entities with government's support and technical basis were supported within this competition. Although it was often clear under more precise studying, that companies doesn 't trust each other or universities colleagues within the cluster. Their common projects were not worked over from the point of logistics and scientific solutions, and it's almost impossible to handle the common deal without confidence and common priorities. In other words, participants have to clear the common interests and expectations, but not only a way to share possible subventions from the state exchequer [3].

In that way, the incorrect approach to cluster's organization is the main problem of "weak" construction cluster in Russia. First, precise understanding of the cluster conception in the classic way, which was developed by M. Porter[13], is needed, while separate brunch of regional economy is being called "cluster" in many Russian regions. Moreover, cluster creation should not happen for political fashion's sake, because a declaration about cluster creation doesn't mean the organization of all conditions for its effective functioning. Actually, some clusters are just legal unions of separate companies without corresponding organizational content $[1,6]$. 


\section{Conclusion}

The regions with formed clusters generally don't issue the challenge of leadership in the country, but they examine clusters as a possibility to overcome their unsatisfactory position. The leader-regions are less motivated in cluster creation, because they have already satisfied their needs. On the other hand, the leader-regions anyway have collected specific weight of intercommunicating organizations of building complex and attendant economic sectors. In addition, on the contrary, there are some regions, which declare creation of a full cluster, but actually, these clusters can just be unions of organizations with poorly organized system of collaboration and intercommunication.

As result, factual clusterization degree in some regions without legal formed clusters is higher, then in regions, where cluster creation was declared. In that way, creation of conditions for cluster functioning and motivation of its potential participants must become the most important task for regional government. As international experience shows, the most powerful clusters appear to be most natural and the initiative of business, science or government is needed only for its formal fastening. Moreover, cluster creating "from above" is often connected with the absence of conditions for its effective functioning.

\section{References}

1. V. L. Abashkin, A. D. Bojarov, E. P. Kutsenko, Forsajt, 3, 16-27 (2012)

2. Bol'she metrov, Ezhenedel'naja delovaja gazeta «Permskij obozrevatel'», 31, 5 (2015)

3. Information on: http://36on.ru/magazine/province/5613-klastery-voronezhskoy-oblastiprovalili-konkurs-minekonomrazvitiya

4. Information on: http://infopro54.ru/news/4423/

5. O.V. Kostenko, Innovacionnaja nauka, 9, 166 (2015)

6. E. P. Kutsenko, Forsajt, 3, 6-15 (2012)

7. Ju.G. Lavrikova, P.N. Kotljarova, Jekonomicheskie i social'nye peremeny: fakty, tendencii, prognoz, 3(33), 173 (2014)

8. O.A. Matveeva, Serija «Jekonomika i jekologicheskij menedzhment», 1, 3 (2014)

9. Information on: http://www.fondvao.ru/580.html

10. Information on http://www.spsi-sro.ru/?id=649

11. Information on: http://economy.krasnodar.ru/strategic-planning/the-program-ofdevelopment-of-krasnodar-region/files/otchet_ser_2013.pdf

12. M.E. Porter, Harvard Business Review November-December, 78-79 (1998)

13. M.E. Porter, Economic development quarterly, 14(1), 15-34 (2000)

14. Information on: http://www.gkp.ru/bgd/regl/b15_14p/Main.htm

15. Information on: http://uecp.ru/uecs-27-272010/item/359-2011-03-25-13-21-41

16. Information on: http://expert.ru/expert/2014/07/nauchilis-delat-megaproektyi/

17. Ju. V. Smirnova, Aktual'nye voprosy jekonomiki i upravlenija: materialy mezhdunar. nauch. Konf, 42-45 (2011)

18. Information on: http://cluster.hse.ru/news/141/

19. B.P. Zhiharevich, Opredelenie perspektivnoj specializacii hozjajstvennogo kompleksa goroda (ocenka profil'nosti), po materialam seminara «Osnovy territorial'nogo strategicheskogo planirovanija na principah shirokogo obshhestvennogo uchastija»Sankt-Peterburg, 13 (2004) 